
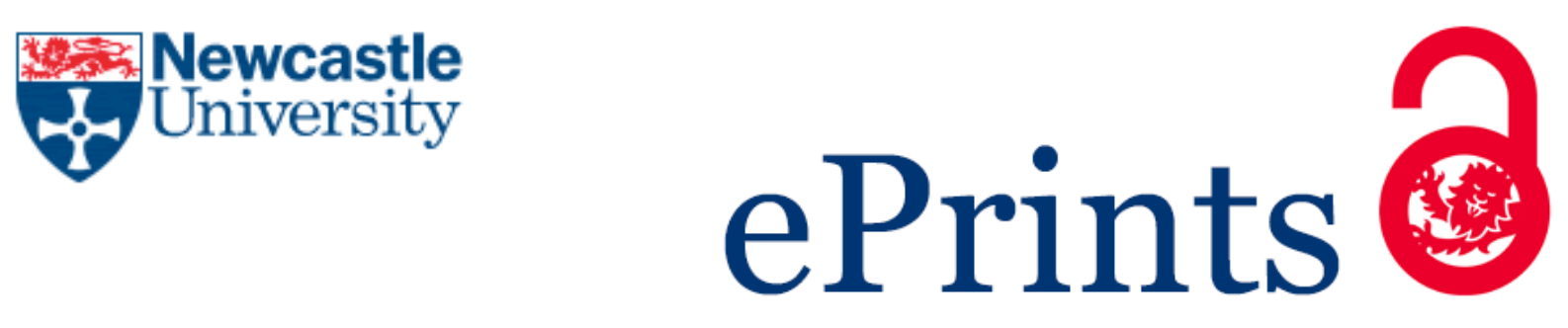

Flynn SL, Gao Q, Robbins L, Warchola TJ, Weston JNJ, Alam MS, Liu Y, Konhauser KO, Alessi DS.

Measurements of bacterial mat metal binding capacity in alkaline and carbonate-rich systems.

Chemical Geology 2017, 451, 17-24.

\title{
Copyright:
}

(C) 2017. This manuscript version is made available under the CC-BY-NC-ND 4.0 license

DOI link to article:

https://doi.org/10.1016/i.chemgeo.2017.01.002

Date deposited:

$19 / 10 / 2017$

Embargo release date:

06 January 2018

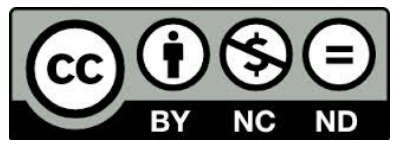

This work is licensed under a

Creative Commons Attribution-NonCommercial-NoDerivatives 4.0 International licence 


\section{Measurements of bacterial mat metal binding capacity in alkaline and carbonate-rich} systems

\author{
Shannon L. Flynn' ${ }^{*}$, Qiyang Gao ${ }^{1,2}$, Leslie J. Robbins ${ }^{1}$, Tyler J. Warchola ${ }^{1}$, Johanna N.J. \\ Weston $^{1,3}$, Md. Samrat Alam ${ }^{1}$, Yuxia Liu' ${ }^{1}$, Kurt O. Konhauser ${ }^{1}$, and Daniel S. Alessi ${ }^{1}$ \\ ${ }^{1}$ Department of Earth and Atmospheric Sciences, \\ University of Alberta, Edmonton, AB T6G 2E3, Canada \\ ${ }^{2}$ Department of Chemical Engineering and Applied Chemistry \\ University of Toronto, Toronto, ON M5S 3E5, Canada \\ ${ }^{3}$ Deparment of Science, \\ University of Alberta Augustana Faculty, Camrose, AB T6B 1T3
}

*Corresponding Author: flynn1@ualberta.ca 
metal adsorption data and directly compare surface reactivity amongst intact mats and mat

27 components. Two of the intact mats exhibited a higher affinity for Cd compared to the mineral at

28 metal equilibrium concentrations above $2.5 \mu \mathrm{M}$, while the other two intact mats had lower

29 affinities under all experimental conditions. Generally, we found the acid-treated mats had higher

$30 \mathrm{Cd}$ adsorption capacities than the carbonate mineral. When compared to their equivalent intact

31 mats, only one acid-treated mat had a higher affinity for Cd. Further, we modelled whether metal

32 adsorption in the intact mats, containing microbes and carbonate mineral, could be explained by a

33 linear combination of the observed metal uptake by the organic and inorganic components through

34 end-member experiments. Metal adsorption additivity results were mixed. Metal uptake by one

35 intact mat was found to be additive, while for the other mat the additive model significantly

36 underestimated the observed Cd accumulation. Our study demonstrates the potential, as well as

37 the limitations, of using modified metal adsorption edges to determine the metal binding affinity

38 and surface reactivity of bacterial mats in alkaline and carbonate-rich systems.

Introduction:

41 Bacteria are found in nearly every environment on Earth, and because of their ubiquity, they play

42 an integral part in the cycling of most elements (see Konhauser, 2007 for details). The initial step

43 in many biogeochemical processes is the adsorption of metal cations to the negatively-charged

44 cellular surfaces (Beveridge and Murray, 1976). The adsorbed cations subsequently facilitate

45 numerous chemical processes including metal reduction (e.g., Newman et al., 1997), oxidation

46 (e.g., Nealson et al., 1988), interacellular accumulation (Southam and Beveridge, 1994), and in

47 many cases, biomineralization (e.g., Ferris et al., 1986). 
Significant work has been undertaken to determine the mechanisms by which metal cations bind to bacteria (Mullen et al., 1989; Fein et al., 1997; Lalonde et al., 2007; Alessi and Fein, 2010). Bacterial cell envelopes contain multiple surface functional groups that have distinct proton and 51 metal binding capacities (Beveridge and Murray, 1980; Fein et al., 1997). Typically, 52 potentiometric titrations of bacterial cells combined with data from bulk metal adsorption 53 experiments to the same bacteria have been used to develop protonation models and metal surface 54 complexation models (SCM), respectively (Cox et al., 1999; Fowle and Fein, 1999; Ngwenya et 55 al., 2003). For the SCM approach, the proton reactivity of a suspension of bacteria is tested by 56 potentiometric titration; that is, by adding precisely-measured aliquots of acid or base to the 57 suspension, and measuring the $\mathrm{pH}$ change due to the addition of that aliquot after equilibrium has 58 been achieved, across a wide $\mathrm{pH}$ range. The buffering capacity measured may then be ascribed to 59 a number of surface functional groups with discrete binding constants (pKa) and site 60 concentrations. Once the surface functional group concentrations and $\mathrm{pKa}$ value(s) have been 61 determined, bulk metal sorption experimental data from either metal adsorption $\mathrm{pH}$ edges (fixed 62 metal concentration with $\mathrm{pH}$ varied) or metal adsorption isotherms (fixed $\mathrm{pH}$ with metal 63 concentration varied) are fitted to determine the metal binding (equilibrium) constants onto the 64 proton-active functional groups calculated from the potentiometric titration data (Fein et al., 1997; 65 Cox et al., 1999; Haas et al., 2001; Ngwenya et al., 2003).

While this body of work demonstrates the potential of bacteria to bind and sequester metal

67 cations, most of these studies have focused on pure cultures of bacteria grown as suspensions under 68 carefully controlled laboratory conditions (e.g., Teitzel and Parsek, 2003). However, most bacteria 69 found in natural environments grow in dynamic multispecies communities, referred to as either 70 biofilms, or their thicker versions, bacterial mats (Kolter and Greenberg, 2006; Elias and Banin, 
71 2012). Mats are also composed of dead cells and exopolymeric substances (EPS) which have been

72 shown increase the number surface reactive sites, measured as $\mathrm{mmol} / \mathrm{g}$, compared to the intact

73 bacterium itself (Baker et al., 2009). The secreted EPS have metal binding properties distinct from

74 the bacterial cells and, therefore, they also impact the adsorption of metal cations from solution by

75 bacterial mats. For example, Spath et al. (1998) measured the distribution of adsorbed cadmium

$76\left(\mathrm{Cd}^{2+}\right)$ and zinc $\left(\mathrm{Zn}^{2+}\right)$ on mats collected from wastewater treatment sequencing batch biofilm

77 reactors. The EPS was found to retain $20 \%$ of the total sorbed metal cations. This indicates that

78 there is a substantial difference between in the behavior of bacterial mats in nature, and the

79 individual cells that make up the mats.

In addition to being composed of bacteria and EPS, mats often incorporate detrital and

81 authigenic or allogenic minerals into their structure (e.g., Konhauser et al., 1998; Jones et al.,

82 2004). These minerals have their own reactivity, which can alter the overall reactivity of the mats

83 (Konhauser and Urrutia, 1999). For instance, Lalonde et al. (2007) applied a SCM approach to

84 model the surface reactivity of intact mats from an alkaline hydrothermal spring in Yellowstone

85 National Park. To determine the mat reactivity they performed acid titrations from $\mathrm{pH} 10$ to 4 , on

86 both intact and acid treated mats. They found that the surface reactivity of the intact mats was

87 dominated by a single surface site with a modeled pKa of approximately 7 , which they attributed

88 to the presence of incorporated carbonate precipitates. With the majority of carbonate precipitates

89 removed, the acid treated mats exhibited an order of magnitude less buffering capacity (measured

90 as mmol protons consumed per g mat) distributed across the tested $\mathrm{pH}$ range of 4 to 10 . While that

91 study was able to determine the relative buffering capacity of the mats, the authors never removed

92 all of the carbonate minerals, meaning that even in their acid treated mat the carbonate minerals

93 likely made a substantial contribution to the overall buffering capacity measured. Additionally, 
94 since titrations were only preformed in a single direction, the reversibility of the system was 95 undetermined. If carbonate dissolution occurred during acid titration, a reverse titration (with base) would have shown hysteresis in the buffering capacity between the forward and reverse titration curves due to this loss of carbonate mineral. The study by Lalonde et al. (2007) highlights the difficulties in determining reactivity in alkaline and carbonate systems and our inability to use potentiometric titrations in the presence of carbonate precipitates or other $\mathrm{pH}$ sensitive precipitates.

In this study, we quantify the reactivity of four different bacterial mats collected from the outflow of an alkaline hot spring located at Fairmont Hot Springs, British Columbia. Because of the reasons described above, traditional methods to probe reactivity, such as potentiometric titrations, adsorption isotherms, and adsorption $\mathrm{pH}$ edges, are likely to be incompatible due to potential interferences caused by the rich abundance of carbonate minerals and the alkaline conditions of Fairmont Hot Springs (Rainey and Jones, 2009). Based on the results of Lalonde et al. (2007), the dissolution of carbonate minerals intertwined with the bacterial component of the intact mats during acid titrations would likely dominate the proton buffering capacity and thereby obscure direct measurement of the proton reactivity of the bacteria in the mat (Warchola et al., in review), which is ultimately key in quantifying the contribution of mat bacteria to overall observed metal removal from solution. Additionally, during metal adsorption $\mathrm{pH}$ edge experiments, the presence of buffering carbonates would limit the $\mathrm{pH}$ range able to be tested. Methods such as metal sorption edges, which are conducted under alkaline conditions, often create conditions in which formation and precipitation of carbonate and hydroxide minerals are favorable. For example, in a system in equilibrium with otavite $\left(\mathrm{CdCO}_{3}\right)$, the total $\mathrm{Cd}$ in solution decreases exponentially as a function of increased $\mathrm{pH}$ (Figure 1). In this case $\mathrm{Cd}$ and otavite are used as proxies for divalent metals and their carbonate precipitates, and clearly illustrate that under increasingly alkaline 
117 conditions greater divalent cation precipitation can be expected. Accordingly, this precludes the 118 investigation of metal adsorption using traditional metal adsorption isotherms for alkaline 119 conditions.

As metal adsorption and the reactivity of bacterial mats are understudied in carbonate rich

121 and alkaline systems, in this study, we propose a method to bypass the issues posed by traditional 122 methods. To address these issues, modified metal adsorption experiments (in which Cd was used 123 as a proxy for environmentally relevant divalent metals) were used to quantify the reactivity of the 124 bacterial mats from a carbonate-rich system under metabolically inactive conditions. To minimize 125 Cd precipitation, the concentration of sorbent (the bacterial mat or mineral) was varied with a 126 constant initial $\mathrm{Cd}$ concentration in lieu of varying the metal concentration. Adsorption is thought 127 to be a fast process occurring on a time scale of seconds to minutes (Xue et al., 1988; Kuyucak 128 and Voelsky, 1989; Matheickal et al., 1999), whereas precipitation of mineral phases is the slower 129 step on a time scale of hours to days (Sadiq, 1992). Therefore, the length of Cd exposure was 130 limited to $4 \mathrm{~h}$ to allow for adsorption to reach equilibrium and to exclude significant precipitation 131 of $\mathrm{Cd}$ as carbonates or hydroxides. In addition to determining the reactivity of intact bacterial mats, 132 reactivity was also determined for travertine (a lithified carbonate sediment associated with 133 microbial mats in hot springs) and two of the bacterial mats that were acid treated to remove the 134 incorporated carbonate minerals. The reactivity of the intact bacterial mats, endmember mineral 135 component, and pure bacterial components (acid treated mats) was quantified through the Cd 136 sequestration potential. By quantifying the potential of not just the intact mats but each endmember 137 component, the contribution of each endmember to the overall observed Cd sequestration in intact 138 mat samples was assessed. 


\subsection{Handling and Collection of Samples}

142 Bacterial mats and travertine samples were collected from an alkaline hot spring located at 143 Fairmont Hot Springs, BC, Canada on September 2, 2015. Material was collected from four 144 distinct bacterial mats, subsequently referred to as: black mat, green mat, spongy green mat, and 145 orange mat (Figure SI.1). The mats were removed from the underlying travertine and placed in 146 polypropylene tubes submerged in water from the hot spring. In addition to bacterial mat and 147 travertine (mineral) samples, water samples were collected for metals analysis. The $\mathrm{pH}$ and 148 temperature were measured during sample collection using a Fisher Science Accumet AP71 149 portable dual $\mathrm{pH}$ and temperature meter along the hot spring flow path (locations shown in Figure 150 SI.1). Water samples were filtered through $0.22 \mu \mathrm{m}$ nylon membranes and acidified with three 151 drops of $12.1 \mathrm{M} \mathrm{HCl}$ for preservation. All samples were placed on ice before transport to the 152 University of Alberta. Samples were stored at $2^{\circ} \mathrm{C}$ prior to analyses.

\subsection{Preparation of Travertine Sample}

155 A travertine mineral sample, which was overlain by the bacterial mats in the field, was collected 156 for reactivity/adsorption experiments because it represents the mineral endmember associated with 157 the bacterial mats. Following collection, the travertine was dried in an oven at $60^{\circ} \mathrm{C}$ for $24 \mathrm{~h}$, then 158 crushed and ground into a fine powder using a mortar and pestle. The powdered travertine was 159 treated to remove any trace organics that may have been incorporated in the travertine using a modified version of the separation method described in Schofield et al. (2008). In summary, the

161 powdered travertine was soaked in $1 \mathrm{M} \mathrm{NaOH}$ for $24 \mathrm{~h}$ before being repeatedly washed with 18.2 $162 \mathrm{M} \Omega$ ultrapure water and centrifuged at 7,000 g; this process was repeated five times. Following 
163 washing, the travertine-water slurry was placed in a separatory funnel with hexane, shaken 164 vigorously and left to separate overnight. The following morning the travertine powder and water 165 was separated from the organics and hexanes, as the latter floated on top as a separate layer. The 166 organics-free travertine was washed with 18.2 M $\Omega$ ultrapure water once more before being 167 centrifuged and decanted twice at 7,000 $\mathrm{g}$ for $5 \mathrm{~min}$, and a final time for $30 \mathrm{~min}$ to form a wet 168 pellet. These wet pellets were subsequently used for metal adsorption experiments and a portion 169 of the organics-free travertine was dried. The dried travertine, with a wet to dry ratio of 1.45 (SI 170 Table 1), was analyzed for mineral composition and surface area using X-ray powder diffraction 171 (XRD) and Brunauer-Emmett-Teller surface area analyzer (BET), respectively.

$174 \mathrm{XRD}$ analysis of the powdered mineral sample was performed using a Rigaku Geigerflex Powder 175 X-ray diffractometer equipped with a cobalt tube, and graphite monochromator and scintillation 176 detector. Data were analyzed using the JADE 9.1 software, with peak locations being referenced 177 using the International Centre for Diffraction Data (ICDD) and Inorganic Crystal Structure 178 Databases (ICSD).

\subsection{Preparation of Bacterial Mat}

181 All four bacterial mat samples were washed and centrifuged 3 times for 5 min at 7,000 g using a 182 prepared stock a solution of $10 \mathrm{mM}$ 4-(2-hydroxyethyl)-1-piperazineethanesulfonic acid (HEPES)

183 buffer and $10 \mathrm{mM} \mathrm{NaCl}$ adjusted to $\mathrm{pH}$. The bacteria were then suspended in approximately 100 $184 \mathrm{ml}$ of the previously described solution on a magnetic stir plate and $\mathrm{pH}$ adjusted using small 
185 aliquots of $1 \mathrm{M} \mathrm{NaOH}$ until the solution $\mathrm{pH}$ stabilized at 8 (the approximate ambient $\mathrm{pH}$ of the hot 186 spring). Bacterial mats were then pelleted by centrifuging and decanting two times for $5 \mathrm{~min}$ and 187 two times for $30 \mathrm{~min}$ at 7,000 $\mathrm{g}$ to produce a compressed wet pellet from each mat. A subsection 188 of each mat was subsequently acid treated with a solution of $0.1 \mathrm{M}$ nitric acid and $10 \mathrm{mM} \mathrm{NaCl}$ to 189 remove carbonate minerals that may have been associated with the bacterial mats. Acid treated 190 bacterial cells have been found to remain intact and viable without any visible difference from 191 their untreated counterparts in previous studies (Fein et al., 1997; Borrok et al., 2004). The acid 192 treatment was performed on a stir plate with continual additions of the $0.1 \mathrm{M}$ nitric acid plus 10 $193 \mathrm{mM} \mathrm{NaCl}$ solution, until the $\mathrm{pH}$ of the bacterial mat suspension had stabilized at or below $\mathrm{pH}$ 4.5.

194 The acid treated mats were then pelleted using the method described above (Section 2.2). Two of 195 the acid treated mats (green and orange) were further treated with the previously described HEPES 196 stock solution until the $\mathrm{pH}$ of the bacterial mat suspension stabilized at 8 . The acid treated mats 197 were then pelleted using the method described above, and are referred to here as 'acid treated green 198 mat' and 'acid treated orange mat'. The mass difference between the pre- and post-acid treated 199 bacterial mat was used to determine the relative bacterial and mineral content of the intact bacterial 200 mats.

203 Batch Cd adsorption experiments were conducted at room temperature $\left(20^{\circ} \mathrm{C}\right)$ and pressure in a 204 matrix of $10 \mathrm{mM}$ HEPES and $10 \mathrm{mM} \mathrm{NaCl}$, adjusted to $\mathrm{pH} 8$. As no nutrients or electron donors 205 were added to the experimental solutions, and the contact time in metal adsorption experiments 206 was short (4 h), the role of potential bacterial metabolism was assumed to be minimal. In contrast 207 to traditional adsorption experiments where the concentration of metal is varied, the concentration 
208 of $\mathrm{Cd}$ added was held constant at $8.89 \mu \mathrm{M}(1 \mathrm{ppm})$ while the sorbent concentration was varied 209 from 0 to $8 \mathrm{~g} / \mathrm{L}$ for the travertine and 0 to $25 \mathrm{~g} / \mathrm{L}$ for the bacterial mats, based on wet weight from 210 the pelleted material. Duplicate experiments were conducted on the travertine, four intact bacterial 211 mats, and two acid treated bacterial mats. In preparation for the experiments, bacterial mat or 212 travertine samples were first added to the solution in polypropylene test tubes; the $\mathrm{pH}$ was then 213 checked and adjusted if needed before the solution was spiked with $\mathrm{Cd}$. Test tubes were rotated 214 end-over-end at $100 \mathrm{rpm}$ for $4 \mathrm{~h}$, adequate time for $\mathrm{Cd}$ adsorption and equilibrium to be achieved 215 but short enough to prevent significant precipitation $(<1.5 \%$, see control experiment in Figure 216 SI.3). The $\mathrm{pH}$ of the solution was measured and adjusted as needed over the first hours of the

217 experiment. At the end of the adsorption experiment, the $\mathrm{pH}$ of each sample was measured and 218 recorded, the tubes centrifuged at 5,000 $\mathrm{g}$ for $5 \mathrm{~min}$, the resulting supernatant subsequently filtered 219 through a $0.2 \mu \mathrm{m}$ nylon membrane, and then diluted 1:10 with $2 \%$ nitric acid before Cd analysis.

2212.6 ICP-MS Analysis

222 Metal analyses of hot spring water and $\mathrm{Cd}$ from adsorption experiments were conducted at the 223 Environmental Geochemistry Laboratory at the University of Alberta using an Agilent 8800 ICP224 MS/MS. A detailed table of the analysis conditions and dilution factors used is provided in Table 225 SI.2.

227 3. Results

228 3.1 Hot Spring Water, Travertine and Bacteria Mat Mineral Analysis

229 Water samples along the flow path were found to show no systematic variation in measured 230 chemical composition, while the $\mathrm{pH}$ increased 1.04 units along the sampled transect and the 
231 temperature decreased by $1.9^{\circ} \mathrm{C}$ (Table SI.3). In total 14 cationic and 1 anionic elements were

232 found to be in quantifiable concentration in hot spring water by ICP-MS/MS analysis. The primary

233 cations in the hot spring water were $\mathrm{Ca}$ and $\mathrm{Mg}$, with $\mathrm{Na}, \mathrm{K}, \mathrm{Si}$, and $\mathrm{Sr}$ also being present in the

234 ppm range; similar to concentrations reported by Warchola et al. (in review) for the same transect.

235 The remaining 8 elemental concentrations were found to be in the ppb range (Table SI.3). Anions

236 were not measured but were assumed to be similar to previous measurements from the same site

237 by Warchola et al. (in review), in which the anions were dominated by alkalinity in the form of

238 carbonate $(380-400 \mathrm{ppm})$, sulphate $(230 \mathrm{ppm})$, and chloride $(26 \mathrm{ppm})$ with a range of ionic

239 strengths between 12-14 mM.

The XRD analysis of powdered travertine mineral from the hot springs was found to be

241 composed of calcite, quartz, dolomite and rutile (Figure SI.2). The calcite likely precipitated in

242 response to the supersaturated state of the solution with respect to $p \mathrm{CO}_{2}$ in water emerging from

243 the subsurface. The dolomite is likely the product of alteration and $\mathrm{Mg}$ exchange in a portion of

244 the calcite. The presence of quartz is likely the result of detrital sand grains entrapped in the 245 carbonate travertine. Rutile, a common paint additive, could be from the inclusion of paint chips 246 washed from the thermal pools at the resort above the sampling site.

The carbonate mineral content of each bacterial mat was determined through acid treatment

248 (Table 1.). The orange mat had the lowest carbonate mineral content, with $32.2 \%$ carbonate

249 minerals by mass. The black and spongy green mats were found to have similar carbonate mineral

250 contents to the orange mat with $36.5 \%$ and $39.8 \%$, respectively. The green mat was composed of

251 significantly more carbonate minerals with $72.8 \%$ of the mat being composed of carbonates, nearly

252 double the content of the other bacterial mats. 
$254 \quad 3.2$ Cd Adsorption Experiments

$255 \quad 3.2 .1$ Travertine

256 The amount of $\mathrm{Cd}$ adsorbed from solution increased with increasing concentration of travertine

257 particles until complete removal of $\mathrm{Cd}$ was achieved at approximately $7.7 \mathrm{~g} / \mathrm{L}$ (Figure 2). From a 258 concentration of $0.06 \mathrm{~g} / \mathrm{L}$ of travertine to $2.0 \mathrm{~g} / \mathrm{L}$, a rapid and near linear increase in the adsorption 259 of Cd was observed. The extent of $\mathrm{Cd}$ adsorbed per $\mathrm{g}$ of travertine decreased from $2.0 \mathrm{~g} / \mathrm{L}$ until $2607.7 \mathrm{~g} / \mathrm{L}$ of travertine where less than $1 \%$ of $\mathrm{Cd}$ was measured to be remaining in solution. Above $2617.7 \mathrm{~g} / \mathrm{L}$ of travertine, near-complete removal of solution Cd was observed.

263 3.2.2 Bacterial Mats

264 3.2.2.1 Green Mat

265 Cd adsorption increased with increasing concentration of green mat until the percent adsorbed 266 plateaued above $15.8 \mathrm{~g} / \mathrm{L}$ of bacterial mat (Figure 3.A). At this concentration or greater, the percent 267 Cd adsorbed was found to be $90-95 \%$ of the total $\mathrm{Cd}$ regardless of increasing concentration of 268 bacterial mat, potentially due to the presence of organic acids in solution that complex Cd. Initially 269 the extent of $\mathrm{Cd}$ adsorption, from 0.041 to $1.2 \mathrm{~g} / \mathrm{L}$ of bacterial mat, was rapid and linear in increase 270 relative to the increase in bacterial mat added. Once the green mat concentration was greater than $271 \quad 1.2 \mathrm{~g} / \mathrm{L}$, and until $15.8 \mathrm{~g} / \mathrm{L}$, the extent decreased before the percent adsorbed plateaued.

272

\section{3.2.2.2 Black Mat}

274 A linear and rapid increase in adsorbed $\mathrm{Cd}$ was observed with increasing black mat concentrations 275 from 0.069 to $1.13 \mathrm{~g} / \mathrm{L}$ (Figure 3.B). Above $1.13 \mathrm{~g} / \mathrm{L}$ of bacterial mat the extent of Cd adsorption 
276 per $\mathrm{g} / \mathrm{L}$ decreased with increasing bacterial mat until $15.9 \mathrm{~g} / \mathrm{L}$ of black mat. Above $15.9 \mathrm{~g} / \mathrm{L}$ of

277 bacterial mat, the percent of $\mathrm{Cd}$ adsorbed plateaus at $82-92 \%$ despite increasing bacterial mat 278 concentration.

279

280

\subsubsection{Spongy Green Mat}

281 The spongy green mat showed a sharp and linear increase in Cd adsorbed with increasing bacterial 282 mat concentration from 0.062 to $1.06 \mathrm{~g} / \mathrm{L}$ (Figure 3.C). The extent of adsorption decreased with 283 increasing spongy green mat concentration from 1.06 to $5.11 \mathrm{~g} / \mathrm{L}$ bacterial mat before the percent 284 adsorbed plateaus at $81-92 \%$ even with increasing bacterial mat concentrations.

286 3.2.2.4 Orange Mat

$287 \mathrm{Cd}$ adsorption to the orange mat increased with increasing mat concentrations until plateauing 288 above $11.00 \mathrm{~g} / \mathrm{L}$ (Figure 3.D). The maximum adsorbed $\mathrm{Cd}$ was found to be between $95-98 \%$ of 289 the initial concentration. At lower concentrations of the orange mat, from 0.048 to $1.12 \mathrm{~g} / \mathrm{L}$, the 290 extent of adsorption is rapid and linear. From 1.12 to $11.00 \mathrm{~g} / \mathrm{L}$ the extent of $\mathrm{Cd}$ adsorption 291 decreases with increasing mat concentrations.

292

293 3.2.3 Acid Treated Bacterial Mats

294 3.2.3.1 Acid Treated Green Mat

295 A linear increase in Cd adsorption was observed with increasing acid treated green mat from 0.069 296 to $0.48 \mathrm{~g} / \mathrm{L}$ (Figure $4 . \mathrm{A}$ ). Above 0.48 to $0.99 \mathrm{~g} / \mathrm{L}$ of bacterial mat, the extent of Cd adsorption 297 decreased with increasing bacterial mat concentration. After $0.99 \mathrm{~g} / \mathrm{L}$, the percent of Cd adsorbed 298 plateaus at 97 to $100 \%$ even with continuing additions of bacterial mat. 


\subsubsection{Acid Treated Orange Mat}

301 The acid treated orange mat showed a rapid and linear increase in the percent of Cd adsorbed with 302 increasing mat concentrations from 0.034 to $0.98 \mathrm{~g} / \mathrm{L}$ (Figure 4.B). The extent of increased 303 adsorption per $\mathrm{g} / \mathrm{L}$ of bacterial mat decreased from 0.98 to $8.10 \mathrm{~g} / \mathrm{L}$ of bacterial mat. Once the 304 concentration of bacterial mat reached $8.10 \mathrm{~g} / \mathrm{L}$ the adsorption of $\mathrm{Cd}$ ranged between $91-100 \%$ of 305 the initial Cd concentration.

\section{Discussion}

308 For this study, metal adsorption to travertine, bacterial mats, and acid treated bacterial mats was 309 modeled using; (1) Freundlich isotherms as a means of determining the relative metal binding 310 affinity, and (2) linear combination fits of the endmember component contributions to the intact 311 mat $\mathrm{Cd}$ adsorption capacity as a means of testing the additivity of metal adsorption in the intact 312 bacterial mats. Freundlich isotherms have been successfully employed to quantify the adsorption 313 capacity of numerous biosorbents, such as marine algae (Kuyucak and Volesky, 1989), fungi 314 (Mullens et al., 1992), and bacteria (Mullens et al., 1989; Volesky and Holan, 1995). The combined 315 experimental data for the duplicate experiments for each sorbent was fitted together using the 316 linearized Freundlich isotherm equation:

$$
\log \left(\mathrm{C}^{*}\right)=\log (\mathrm{K})+\mathrm{N} * \log (\mathrm{C})
$$

318 in which $\mathrm{C}$ and $\mathrm{C}^{*}$ represent the equilibrium $\mathrm{Cd}$ concentration in solution $(\mu \mathrm{m})$ and the adsorbed 319 Cd concentration $(\mu \mathrm{m} / \mathrm{g})$, respectively, and $\mathrm{N}$ and $\mathrm{K}$ are Freundlich constants. In this form, the K 320 constant represents the affinity of the sorbent for $\mathrm{Cd}$ in $\mu \mathrm{m} / \mathrm{g}$ at an equilibrium solution 321 concentration of $1 \mu \mathrm{m}$. The linearized Freundlich equation fits the $\mathrm{Cd}$ adsorption data for 
322 environmental samples well (Table 2), with coefficient of determination values ranging from 0.86

323 to 0.96 (insets in Figures 2, 3A-D, and 4A-B).

At low metal concentrations, those below $1 \mu \mathrm{M}$ equilibrium $\mathrm{Cd}$ in solution, travertine 325 shows the highest modeled affinity for $\mathrm{Cd}$ (See Figure 5). The second highest affinity in this range 326 was predicted to be for the acid treated green mat, which along with travertine at $1 \mu \mathrm{M}$, had an 327 affinity that was double that of all other sorbents. Above $1 \mu \mathrm{M}$ the affinity of travertine for $\mathrm{Cd}$ 328 increases more slowly relative to the other sorbents, as indicated by the corresponding $\mathrm{N}$ values 329 (Table 2). Once the equilibrium Cd solution concentration reaches $7.5 \mu \mathrm{M}$, the affinity of travertine 330 for $\mathrm{Cd}$ is only greater than that of the intact black mat, and at or above $10 \mu \mathrm{M}$ equilibrium $\mathrm{Cd}$ in 331 solution travertine has the lowest overall Cd affinity.

Among the intact mats, which include both the microbial biomass and carbonate solids, the orange mat has the highest $\mathrm{Cd}$ affinity at equilibrium concentration below $3 \mu \mathrm{M}$; above $3 \mu \mathrm{M}$ the 334 green mat has the highest affinity with the orange mat having the second highest. The spongy green 335 and black mats are predicted by the models to have lower affinity for $\mathrm{Cd}$ than the green and orange 336 mats throughout the entire examined $\mathrm{Cd}$ concentration range. Of these two intact mats, the black 337 mat is predicted to have the higher affinity for $\mathrm{Cd}$ when the metal concentration is below $4.5 \mu \mathrm{M}$, 338 and vice versa above $4.5 \mu \mathrm{M}$.

Of the two acid treated mats tested, the green mat has a higher predicted affinity for $\mathrm{Cd}$ 340 over the entire range examined. When compared to the intact green mat, the acid treated green mat 341 was found to have approximately twice the affinity for $\mathrm{Cd}$. In contrast the acid treated orange mat 342 exhibited lower Cd affinity, approximately half that of the intact orange mat. 
To determine whether metal adsorption by the intact mats is additive (that is, if it can be 344 modelled as the sum of its constituent components), a component additivity modeling approach 345 utilizing acid treated mat (biomass only) and travertine-only endmembers was applied to measured 346 Cd adsorption data from the corresponding intact mats. Using this approach, it can be determined 347 whether $\mathrm{Cd}$ adsorption to the components of the intact mats is additive, or if when combined, the 348 sum of the $\mathrm{Cd}$ adsorption to the individual components show synergistic or antagonistic 349 relationships that impact overall Cd removal from solution (Alessi and Fein, 2010). A composite 350 model composed of the sum of the adsorption capacity of individual mat components, similar to 351 that used by Small et al. (1999) for bacteria-Fe(III) composites, was used to determine the 352 additivity of the bacterial mats. The composite $\mathrm{Cd}$ removal from solution $\left(\mathrm{C}^{*}\right.$ Comp. $)$, which 353 represents the predicted $\mathrm{Cd}$ removal by intact mats, was calculated as the sum of the intact mat 354 components, according to:

$$
\text { \%Bac. } * \mathrm{C}_{\text {Bac. }}^{*}+\% \text { Min. } * \mathrm{C}_{\text {Min. }}^{*}=\mathrm{C}_{\text {Comp. }}^{*}
$$

356 in which the sum of the predicted component $\mathrm{Cd}$ affinity, $\mathrm{C}^{*}$ Bac. (acid treated bacterial mat) and $357 \mathrm{C}^{*}$ Min. (travertine) are multiplied by their respective mass percent in the intact bacterial mat. The 358 calculated $\mathrm{Cd}$ removal ( $\mathrm{C}^{*}$ Comp.) was then substituted for $\mathrm{C}^{*}$ in Equation 1 to calculate the 359 hypothetical composite model $\mathrm{Cd}$ removal across a range of $\mathrm{Cd}$ concentrations. Overall, the 360 composite model for the green mat reasonably matches the Freundlich fit to the intact green mat 361 Cd adsorption data (Table 2 and Figure SI.4.A,B), but overestimates affinity for Cd at low 362 concentrations (below $6 \mu \mathrm{m}$ ) and underestimates mat $\mathrm{Cd}$ affinity at higher equilibrium $\mathrm{Cd}$ 363 concentrations in solution above $6.5 \mu \mathrm{m}$. The composite orange mat underestimates the adsorbed 364 Cd concentration once the equilibrium solution $\mathrm{Cd}$ concentration is above $0.95 \mu \mathrm{M}$, or across the 365 majority of the experimental range. 
As a second test of the component additivity of the system, a subtractive model (equation

3 ), was created to assess if the adsorption behavior of travertine and an intact mat could be used to calculate the adsorption behavior of the bacteria-only component of that mat, as represented by the acid treated mat. In this model, the total concentration of $\mathrm{Cd}$ adsorbed to the intact mat $\left(\mathrm{C}^{*}{ }_{\text {Tot. }}\right)$ is subtracted by the product of the percent travertine by mass (\%Min.) in the mat and the concentration adsorbed to the travertine $\left(\mathrm{C}^{*}\right.$ Min. $)$, and then divided by the percent mass of bacteria in the intact mat determined through acid treatment (\%Bac.), giving the concentration of $\mathrm{Cd}$ that should be adsorbed on the bacterial component of the mat $\left(\mathrm{C}^{*} \mathrm{Bac}.\right)$, according to:

$$
\frac{C_{\text {Tot. }}^{*}{ }^{-} \text {Min.* } C^{*}{ }_{\text {Min. }}}{\% \text { Bac. }}=C^{*}{ }_{\text {Bac. }}
$$

The subtractive models fitting parameters are shown in 2 and Figure SI.5. The subtractive model for the green mat overestimates the affinity of the acid treated green mat for $\mathrm{Cd}$, once the equilibrium solution $\mathrm{Cd}$ concentration is above $3.0 \mu \mathrm{M}$. In contrast, the subtractive model for the orange mat overestimates Cd adsorption onto the bacterial component of acid treated orange mat over the entire experimental range. The overestimation for both the subtractive green and orange mats could be caused by a difference in the size of reactive mineral particles used as the inorganic endmember and particle size found in the mats. If the particles found in the mats were smaller than those used as the mineral endmember, then the mineral contribution would have likely been underestimated due to the difference in the reactive surface area. Another possibility is that $\mathrm{Ca}$ and $\mathrm{Mg}$ are released during travertine dissolution in the intact mats. Then, the $\mathrm{Ca}$ and $\mathrm{Mg}$ compete with $\mathrm{Cd}$ for adsorption to surface sites within the bacterial components of the mat. The competition is expected to be minimal as binding constants for $\mathrm{Ca}^{2+}$ and $\mathrm{Mg}^{2+}$ to the model bacterium Bacillus subtilis are two orders of magnitude lower than that for the binding of $\mathrm{Cd}^{2+}$ (Flynn et al., 2014). This underestimation would then result in the overestimation of the bacterial component 
contribution, as our models are too simplistic to represent the true complexity of the mat. The subtractive models for the spongy green and black mats were found to have higher $\mathrm{N}$ values than those for the green and orange mats, however, the $\mathrm{K}$ values were significantly lower. Over the range examined, the bacterial component of the green mat is modeled to have the highest $\mathrm{Cd}$ metal sorption followed by the bacterial component in the orange, spongy green, and black mats.

In alkaline and carbonate systems, metals can be incorporated into carbonate precipitates by either abiotic or biotic processes. Abiotic partitioning of alkali earth elements into carbonates has been found to be more significant into aragonite than calcite, with incorporation increasing with decreased ionic radius (Okumura and Yasushi, 1986). Additionally, the partitioning of divalent metals into carbonate minerals is affected by their depth in the water column (Elderfield et al., 1996) and divalent metals have been shown to coordinate at $\mathrm{Ca}$ sites on calcite, forming mononuclear inner-sphere adsorption complexes (Elzinga and Reeder, 2002). At present it is not known whether the same mechanism of trace metal incorporation into carbonates minerals occurs via biotic processes. However, the first step is likely adsorption of $\mathrm{Ca}^{2+}$ ions to the negatively charged bacterial surface sites or negatively charged bacterial mat surface sites (a combination of bacterial surface sites and EPS surface sites) (Thompson and Ferris, 1990; Braissant et al., 2007). The surface sites act as nucleation points from which carbonate minerals can grow using the bacterial surface as a template. Indeed, a number of different carbonate phases can form by simply replacing $\mathrm{Ca}$ for other divalent cations in the growth media, e.g., $\mathrm{Fe}^{2+}$ to form siderite (Mortimer et al., 1997) and $\mathrm{Sr}^{2+}$ to form strontianite (Schultze-Lam and Beveridge, 1994). In addition to the $\mathrm{Ca}$ being incorporated into the biogenic carbonate precipitates, other metals (i.e., $\mathrm{Cd}, \mathrm{Cu}, \mathrm{Zn}, \mathrm{Pb}$, REEs, Sr) bound to the bacterial mats could also be incorporated into the carbonate precipitates nucleating on the bacterial mat. For instance, previous studies have documented that cyanobacteria 
412 can partition of up to $1.0 \mathrm{wt} \%$ strontium in calcite (Ferris et al., 1995). This has important 413 implications for trace metal incorporation into biogenic minerals in the environment because 414 passive carbonate biomineralization may provide a useful strategy for contamination issues in Ca 415 carbonate-rich aquifers (Warren et al., 2001).

This study demonstrates the possibility to probe and measure metal reactivity in alkaline-

417 and carbonate-rich systems by altering traditional metal adsorption experiments - using a low and 418 consistent initial metal concentration, varying the bacterial mat concentration, and shortening the 419 exposure time. While this method may be expanded upon or altered to elucidate additional 420 information about the bacterial mat reactivity, our modified metal adsorption experiments have 421 shown the ability to determine the relative Cd affinity of several bacterial mats from a hot spring 422 under varied metal loading conditions, and provides a first step in determining which of the metal 423 immobilization mechanisms discussed above may be important in alkaline and carbonate-rich 424 systems. Differences in the metal binding between the mats likely was due to the differences in 425 the ratio of biological material to travertine/mineral phases and the ratio of bacterial cells to EPS 426 present in the mats. The reactivity of the bacteria within the mats is not thought to be strongly 427 influenced by the species of bacteria present, as previous work by Borrok et al. (2005) found 428 remarkable similarities in the reactivity of 36 separate bacterial species and consortia. Our method 429 showed mixed results in determining the relative additivity of mat biological and inorganic 430 components toward the total reactivity of the intact mat. The mixed results with regards to system 431 additivity may have stemmed from a variety of differences in the mats, including density of the 432 biological material, diffusion of $\mathrm{Cd}$ through the mat, and detrital inorganic grain size. Further work 433 will be needed to determine whether adsorption of metals to bacterial surface functional groups is 434 the precursory step for metal incorporation into biogenic carbonates. Future studies are also needed 
435 to explore how the adsorption of metal onto bacterial mats affects metal incorporation to 436 microbially-induced carbonates, and to assess the relative contribution of biotic or abiotic 437 mechanisms to the formation of microbial mat carbonates. By continuing to study bacterial mat 438 reactivity in alkaline- and carbonate-rich systems, we may be able to determine these controls on 439 metal partitioning into biogenic carbonates, and thereby further our understanding of metal cycling 440 and sequestration in relevant modern environments, ranging from hot springs to oceans.

\section{Conclusions}

This study demonstrates the potential and limitations of using modified metal adsorption 443 edges to determine the metal binding affinity and surface reactivity of metabolically inactive

444 bacteria in alkaline and carbonate-rich systems, such as in bacterial mats that have authigenic 445 carbonate minerals. The empirical models were effective in determining which of the Fairmont 446 Hot Springs' bacterial mats had the highest metal adsorption potential. However, the results were 447 mixed when the additivity of the bacterial mat components, mineral, and bacteria, were measured 448 separately and the sum of their relative contributions used to create additive models. This study 449 highlights the potential as well as limitations of using modified metal adsorption edges to 450 determine the metal binding affinity and surface reactivity of natural bacteria in alkaline and 451 carbonate-rich systems.

Models such as the ones presented in this paper expand our understanding of bacterial mat 453 reactivity in alkaline and carbonate rich systems. Further studies are required to transition from 454 modeling reactivity in these complex systems with empirical models, such as Freundlich or 455 Langmuir isotherms, to thermodynamic models, such as surface complexation models. The current 456 limit in transitioning to thermodynamically driven models is our inability to measure proton 
457 reactivity in the presence of carbonate minerals and in turn to quantify the number of surface sites

458 could adsorb metals. While metals can be used as a probe for overall mat reactivity, the reactivity

459 of bacterial mats will vary based on the metal tested (depending on, i.e., charge and hydrodynamic

460 radius), interactions between individual sorbents in the intact mat, and potential diffusional or

461 kinetics effects. Therefore, further work is required to constrain proton reactivity of the biomass

462 component of intact mats, and to provide improved methods for predicting total reactivity of mats

463 toward metals in alkaline and carbonate rich systems.

\section{Acknowledgements:}

465 This work was supported by Discovery Grants from the Natural Sciences and Engineering 466 Research Council of Canada (NSERC) to Daniel Alessi and Kurt Konhauser. Leslie Robbins 467 gratefully acknowledges the support of a NSERC Vanier CGS, and Tyler Warchola a NSERC

468 CGS-M. We also would like to acknowledge the staff of the Fairmont Hot Spring Resort for 469 providing us with access to the site, as well as working space to set up a temporary lab. In addition, 470 we thank the two reviewers for their insightful and pointed reviews which greatly aided in the 471 improvement of this manuscript. 


\section{References:}

475 Alessi DS, and Fein JB (2010) Cadmium adsorption to mixtures of soil components: Testing the component additivity approach, Chem. Geol., 270, 186-195.

477 Baker MG, Lalonde Sv, Konhauser KO, and Foght JM (2009) Role of extracellular polymeric 478 sustances in the surface chemical reactivity of Hymenobacter aerophilus, a psychrotolerant 479 bacterium, Appl. Environ. Microbiol., 76, 102-109.

480

481

482

483

484

485

486

487

488

489

490

491

492

493

494

495

496

497

498

499

500

501

502

503

504

505

Beveridge TJ, and Murray RGE (1976) Uptake and retention of metals by cell-walls of Bacillus subtilis, J. Bacteriol., 127, 1502-1518.

Beveridge TJ, and Murray RGE (1980) Sites of metal-deposition in the cell wall of Bacillus subtilis, J. Bacteriol., 141, 876-887.

Braissant O, Decho AW, Dupraz C, Glunk C, Przekop KM, and Visscher PT (2007)

Exopolymeric substances of sulfate-reducing bacteria: interactions with calcium at alkaline $\mathrm{pH}$ and implication for formation of carbonate minerals, Geology, 5, 401-411.

Borrok D, Fein JB, Tischler M, O’loughlin E, Meyer H, Liss M, and Kemner KM (2004) The effects of acidic solutions and growth conditions on the adsorptive properties of bacterial surfaces, Chem. Geol., 209, 107-119.

Borrok D, Turner BF, and Fein JB (2005) A universal surface complexation framework for modeling proton binding onto bacterial surfaces in geologic settings, Am. J. Sci., 305, 826-853.

Cox JS, Smith DS, and Ferris FG (1999) Characterizing heterogeneous bacterial surface functional groups using discrete affinity spectra for proton binding, Environ. Sci. Technol., 33, 45144521.

Elderfield H, Bertram CJ, and Eraz J (1996) A biomineralization model for the incorporation of trace elements into foraminiferal calcium carbonate, Earth Planet. Sci. Lett., 142, 490-423.

Elias S and Banin E (2003) Multi-specis biofilms: living with friendly neighbors, FEMS Microbiol. Reviews, 36, 990-1004.

Elzinga EJ, and Reeder RJ (2002) X-ray absorption spectroscopy study of $\mathrm{Cu}^{2+}$ and $\mathrm{Zn}^{2+}$ adsorption complexes at the calcite surface: Implications for site-specific metal incorporation preferences during calcite crystal growth, Geochim. Cosmochim. Acta, 66, 3943-3954.

Fein JB, Daughney CJ, Yee N, and Davis TA (1997) A chemical equilibrium model for metal adsorption onto bacterial surfaces, Geochim. Cosmochim. Acta, 16, 3319-3228.

Ferris FG, Beveridge TJ, and Fyfe WS (1986) Iron-silica crystallite nucleation by bacteria in a geothermal sediment, Nature, 320, 609-611. 
Ferris, F.G., Fratton, C.M., Gerits, J.P., Schultze-Lam, S., and Sherwood Lollar, B. (1995) Microbial precipitation of a strontium calcite phase at a groundwater discharge zone near Rock Creek, British Columbia, Canada. Geomicrobiol. J., 13, 57-67.

Flynn SL, Szymanowski JES, and Fein JB (2014) Modeling bacterial metal toxicity using a surface complexation approach, Chem. Geol., 374, 110-116.

Fowle DA and Fein JB (1999) Competitive adsorption of metal cations onto two gram positive bacteria: testing the chemical equilibrium model, Geochim. Cosmochim. Acta, 63, 3059-3067.

Haas JR, Dichristina TJ, and Wade R (2001) Thermodynamics of U(VI) sorption onto Shewanella putrefaciens, Chem. Geol., 49, 609-611.

Jones, B., Konhauser, K., Renaut, R.W. and Wheeler, R. (2004) Microbial silicification in Iodine Pool, Waimangu geothermal area, North Island, New Zealand: Implications for recognition and identification of ancient silicified microbes. Geological Society of London, 161, 983-993.

Kolter R, and Greenberg PE (2006) Microbial sciences: the superficial life of microbes, Nature, 441, 300-302.

Konhauser KO (2007) Introduction to Geomicrobiology, Blackwell Publishing, Oxford, UK.

Konhauser, K.O., Fisher, Q.J., Fyfe, W.S., Longstaffe, F.J., and Powell, M.A. (1998) Authigenic mineralization and detrital clay binding by freshwater biofilms: The Brahmani River, India. Geomicrobiol. J., 15, 209-222.

Konhauser KO, and Urrutia MM (1999) Bacterial clay authigenesis: a common bacterial process, Chem. Geol., 161, 399-413.

Kuyucak N and Volesky B (1989) Accumulation of cobalt by marine alga, Biotechnol. Eng., 33, 809-814.

Lalonde SV, Amskold L, Warren LA and Konhauser KO (2007) Surface chemical reactivity and metal adsorptive properties of natural cyanobacterial mats from an alkaline hydrothermal spring, Yellowstone National Park, Chem. Geol., 243, 36-52.

Matheichal JT, Yu Q, and Woodburn G.M. (1999) Biosorption of cadmium (II) from aqueous solution by pre-treated biomass of marine alga Durvillaea potatorum, Water Res., 33, 335-342.

Mortimer, R.J.G., Coleman, M.L., and Rae, J.E. (1997) Effect of bacteria on the elemental composition of early diagenetic siderite: Implications for palaeoenvironmental interpretations. Sedimentology, 44,759-765.

Mullens MD, Wolf DC, Ferris FG, Beveridge TJ, Flemming CA, and Bailey GW (1989) Bacterial sorption of heavy metals, Appl. Environ. Microbiol., 55, 3143-3149.

Mullens MD, Wolf DC, Beveridge TJ, and Bailey GW (1992) Sorption of heavy metals by soil fungi Aspergillus Niger and Mucor Rouxii, Soil Biol. Biochem., 24, 129-135.

Nealson, K.H., Tebo, B.M., and Rosson, R.A. (1988) Occurrence and mechanisms of microbial oxidation of manganese. Adv. Appl. Microbiol., 33,279-318. 
Newman, D.K., Beveridge, T.J., and Morel, F.M.M. (1997) Precipitation of arsenic trisulfide by Desulfotomaculum auripigmentum. Appl. Environ. Microbiol., 63,2022-2028.

Ngwenya BT, Sutherland IW, and Kennedy L (2003) Comparison of the acid-base behavior and metal adsorption characteristics of gram-negative bacterium with other strains, Appl. Geochem., 18, 527-538.

Okumura M and Yasushi M (1986) Coprecipitation of alkali metal ions with calcium carbonate, Geochim. Cosmochim. Acta, 50, 49-58.

Rainey RK, and Jones B (2009) Abiotic versus biotic controls on the development of the Fairmont Hot Spring carbonate deposite, British Columbia, Canada, Sedimentology, 56, 18321857.

Sadiq M (1992) Basic concepts in Marine Chemistry, In: Toxic metal chemistry in marine environments, Marcel Dekker Inc., New York, pp 5-29.

Schofield EJ, Veeramani H, Sharp JO, Suvorova E, Latmani RB, Mehta A, Stahlman J, Webb SM, Clark DL, Conradson SD, Ilton ES, and Bargar JR (2008) Structure of biogenic uraninite produced by Shewanella onedensis strain MR-1, Environ. Sci. Technol., 42, 7898-7904.

Schultze-Lam, S. and Beveridge, T.J. (1994) Nucleation of celestite and strontionite on a cyanobacterial S-layer. Appl. Environ. Microbiol., 60, 447-453.

Small TD, Warren LA, Roden EE, and Ferris FG (1999) Sorption by bacteria, Fe(III) oxide, and Bacteria-Fe(III) oxide composites, Environ. Sci. Technol., 33, 4465-4470.

Spath R, Flemming HC, and Wuertz S (1998) Sorption properties of biofilms, Wat. Sci. Tech., 37, 207-210.

Southam, G. and Beveridge, T.J. (1994) The in vitro formation of placer gold by bacteria. Geochim. Cosmochim. Acta, 58,4527-4530.

Teitzel GM, and Parsek MR (2003) Heavy metal resistance of biofilm and planktonic Pseudomonas aeruginosa, Appl. Environ. Microbiol., 69, 2313-2320.

Thompson, J.G. and Ferris, F.G. (1990) Cyanobacterial precipitation of gypsum, calcite, and magnesite from natural alkaline lake water. Geology, 18,995-998.

Warchola TJ, Flynn SL, Robbins LJ, Liu Y, Meyers R, Gauger T, Kovalchuk O, Alam MS, Wei S, Lalonde SV, Kappler A, Alessi DS, and Konhauser KO (in review) Field- and lab-based potentiometric titrations of microbial mats from the Fairmont Hot Springs, Canada, Geomicrobiol. J.

Warren, L.A., Maurice, P.A., Parmar, N., and Ferris, F.G. (2001) Microbially mediated calcium carbonate precipitation: Implications for interpreting calcite precipitation and for solid phase capture of inorganic contaminants. Geomicrobiol. J.,18, 93-115.

Volesky B and Holan ZR (1995) Biosorption of heavy metals, Biotechnol. Prog., 11, 235-250. 
577 Xue HB, Stumm W, and Sigg L (1988) The binding of metals to algal surfaces, Water Res., 22, 578 917-926. 
580 Tables and Figures:

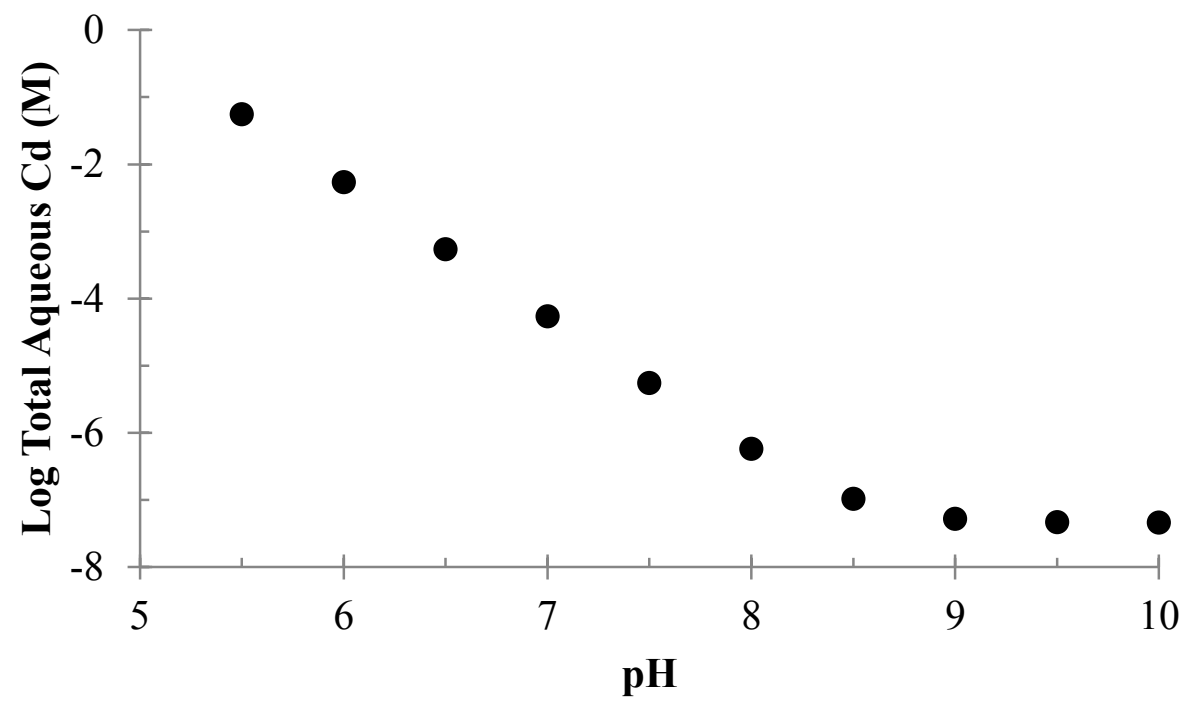

581

582 Figure 1. Total $\mathrm{Cd}$ in solution in equilibrium with otavite as a function of $\mathrm{pH}$.

583 Table 1. Partitioning of mass between bacteria and carbonate mineral in the intact bacterial mats.

\begin{tabular}{|l|r|r|}
\hline & \% Mineral & \% Bacteria \\
\hline Spongy Green Mat & 39.8 & 60.2 \\
\hline Black Mat & 36.5 & 63.5 \\
\hline Orange Mat & 32.1 & 67.9 \\
\hline Green Mat & 72.8 & 27.2 \\
\hline
\end{tabular}

584

585 


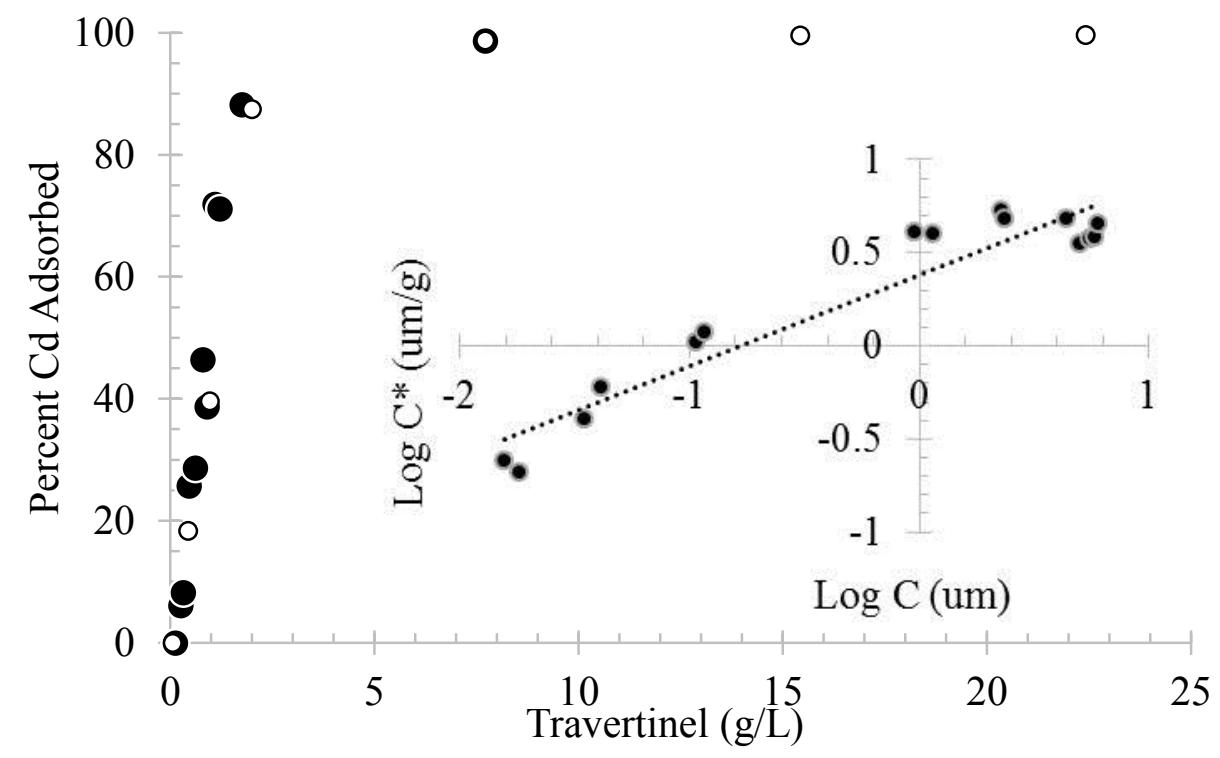

588 Figure 2. Results of duplicate experiments measuring $\mathrm{Cd}$ adsorption onto the travertine from 589 Fairmont Hot Springs plotted as the percentage of $\mathrm{Cd}$ adsorbed to the travertine as a function of 590 Travertine concentration with the fit of the linear form of the Freundlich isotherm equation inset. 


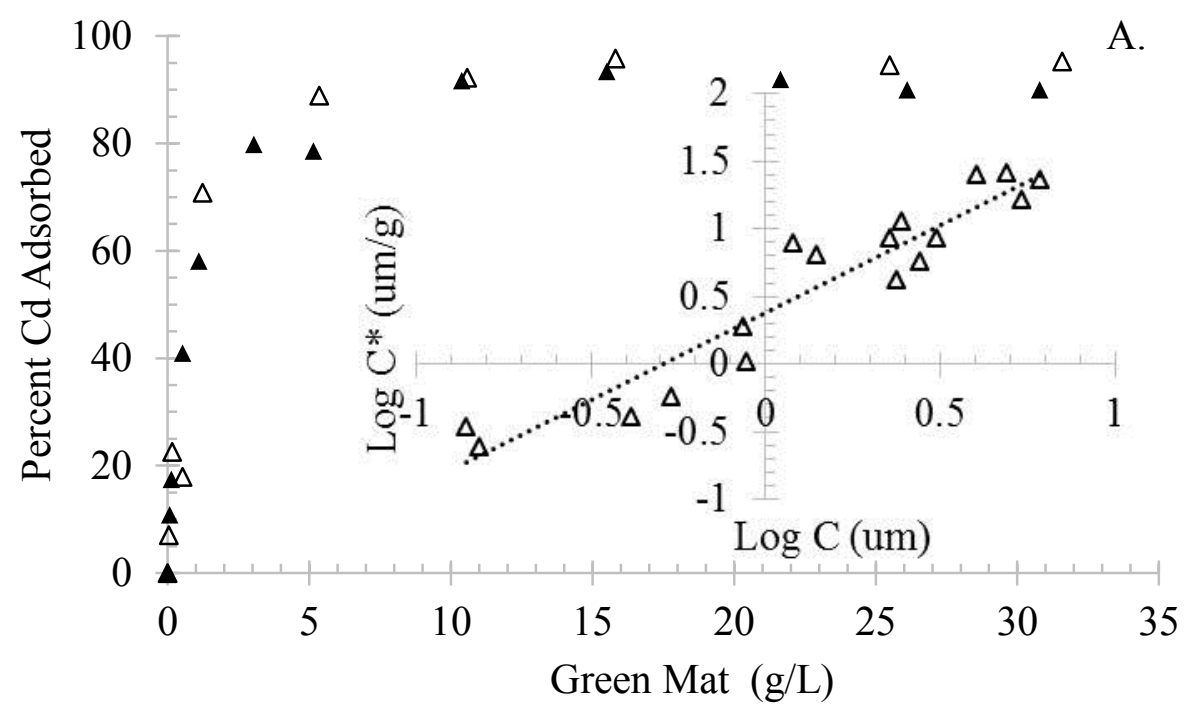

593

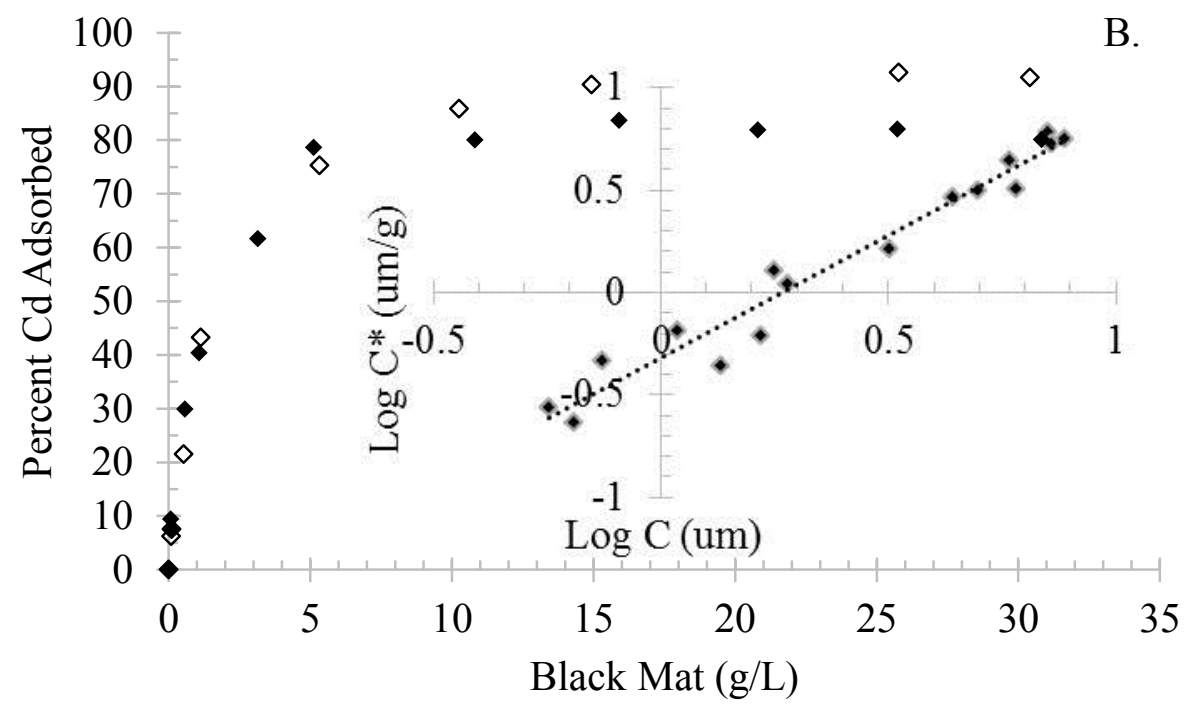




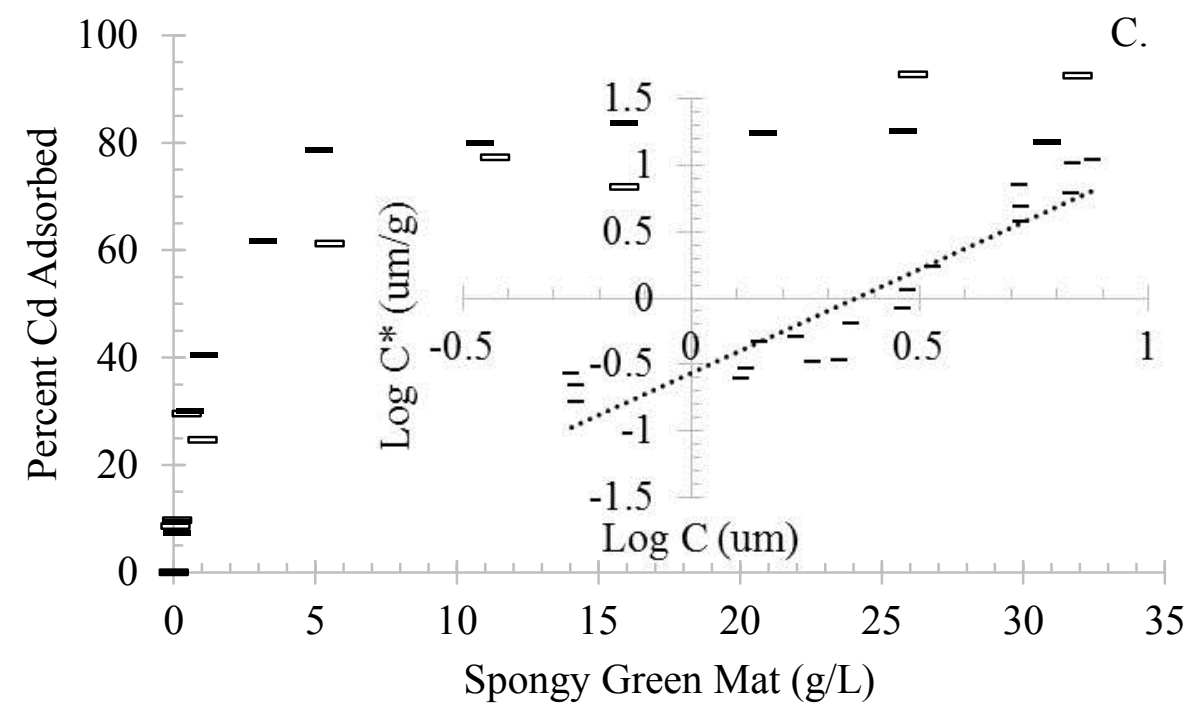

595

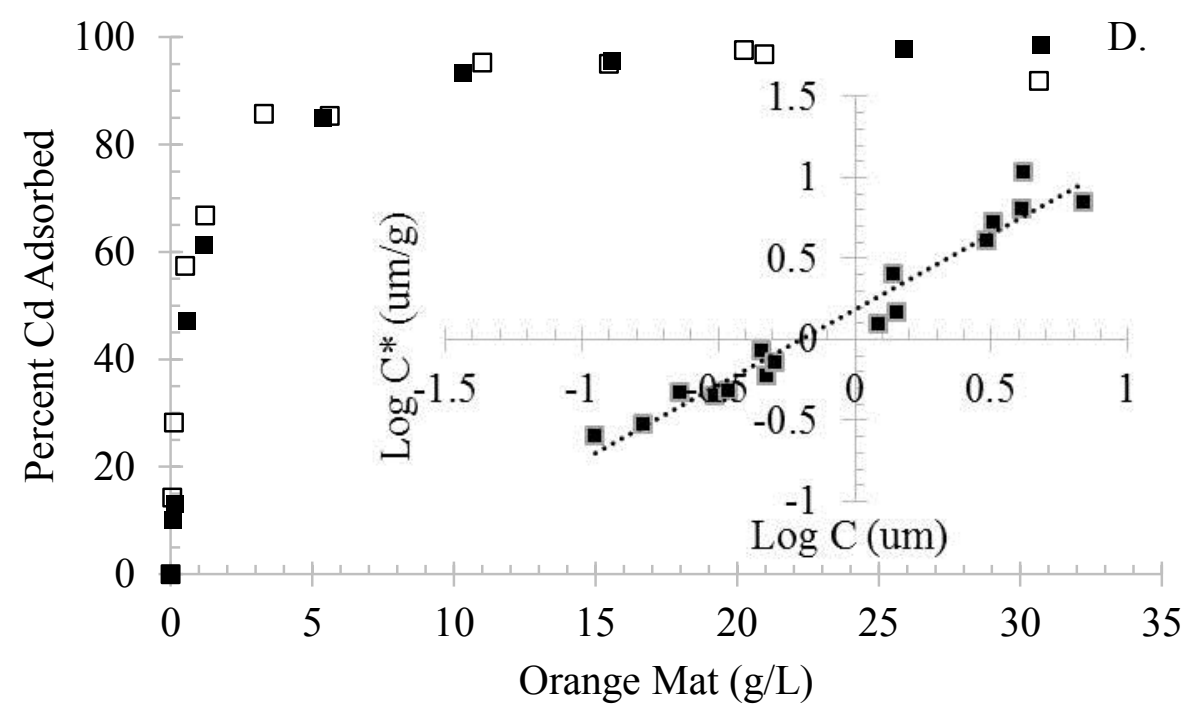

597 Figure 3. Cd adsorption to each of the bacterial mats plotted as percent $\mathrm{Cd}$ adsorbed as a function 598 of the bacterial mat concentration with the respective fits of their linear form of the Freundlich 599 isotherm equation inset (A. green mat, B. black mat, C. spongy green mat, and D. orange mat). 


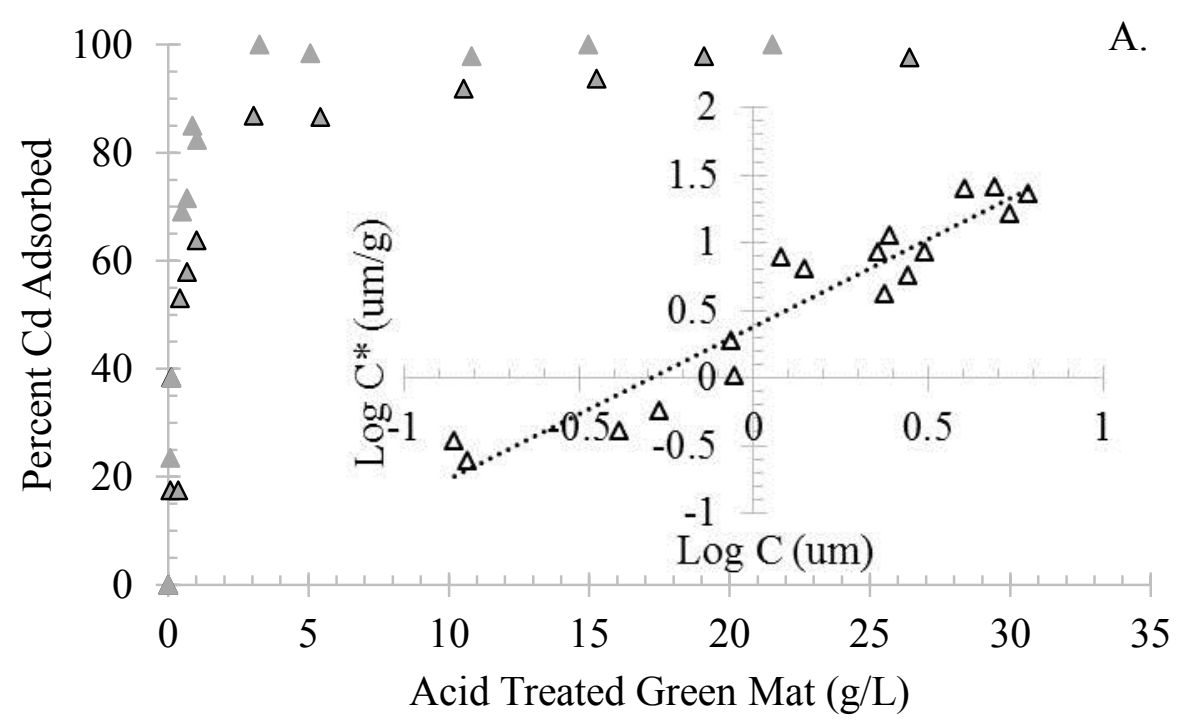

600

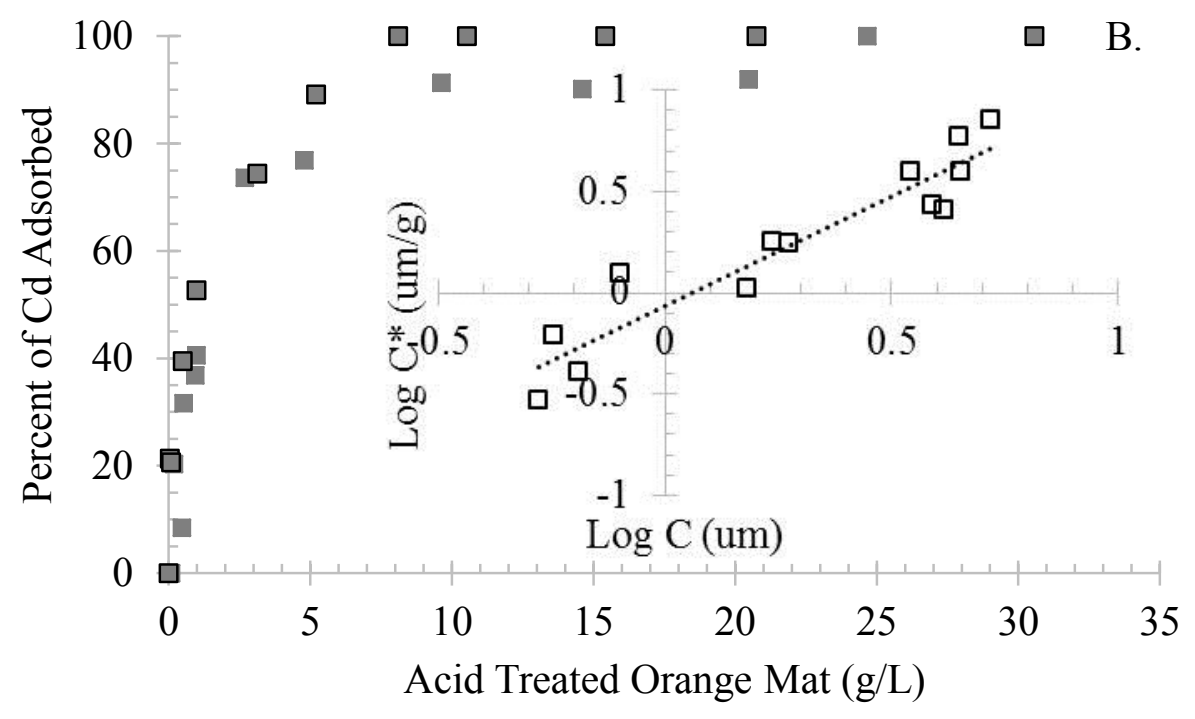

601

602 Figure 4. Cd adsorption to the acid treated bacterial mats plotted as percent $\mathrm{Cd}$ adsorbed as a 603 function of the bacterial mat concentration with the respective fits of their linear form of the 604 Freundlich isotherm equation inset (A. acid treated green mat, B. acid treated orange mat). 
609

610

611 Figure 5. Models of the predicted adsorbed Cd concentrations $\left(\mathrm{C}^{*}\right)$ based on the Freundlich 612 isotherm, including travertine mineral (grey line), green mat (dark green line), black mat (black 613 line), Spongy green mat (light green line), orange mat (orange line), acid treated green mat 614 (dashed green line), and acid treated orange mat (dashed orange line). 